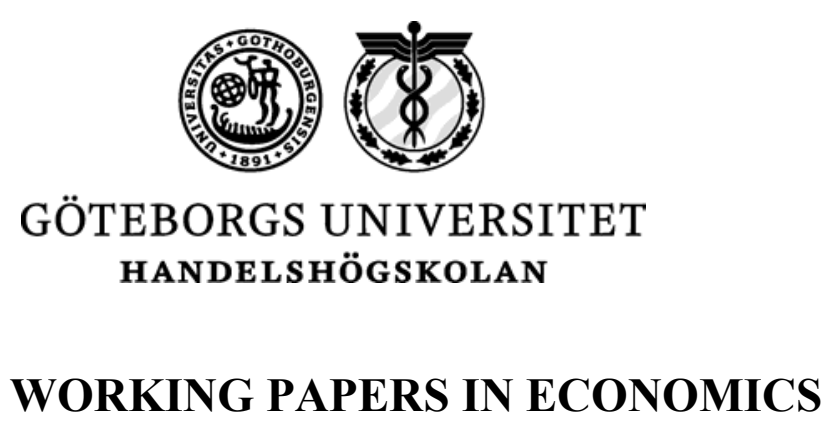

No 326

Tradable Permits in Developing Countries: Evidence from air pollution in Santiago, Chile

Jessica Coria and Thomas Sterner

November, 2008

ISSN 1403-2473 (print)

ISSN 1403-2465 (online)

Institutionen för nationalekonomi med statistik

Handelshögskolan vid Göteborgs universitet

Vasagatan 1, Box 640, SE 40530 Göteborg

0317860000,0317861326 (fax)

www.handels.gu.se info@handels.gu.se 


\title{
Tradable Permits in Developing Countries: Evidence from air pollution in Santiago, Chile
}

\author{
Jessica Coria ${ }^{\bullet}$ \\ Thomas Sterner
}

Gothenburg University

\begin{abstract}
Santiago was one of the first cities outside the OECD to implement a tradable permit program to control air pollution. This paper looks closely at the program's performance over the past ten years, stressing its similarities and discrepancies with trading programs implemented in developed countries, and analyzing how it has reacted to regulatory adjustments and market shocks. Studying Santiago's experience allows us to discuss the drawbacks and advantages of applying tradable permits in less developed countries
\end{abstract}

Keywords: Air pollution, environmental policy, tradable permits, developing countries.

JEL Classification: Q53, Q58.

\section{INTRODUCTION}

Policy makers have paid increasing attention to market based policy instruments over the last decades. Tradable emission permits have been at the center of this discussion due to the theoretical promise of cost-effectiveness and because they have been used successfully in the United States to reduce sulphur dioxide $\left(\mathrm{SO}_{2}\right)$ and nitrogen oxides (NOx). However, it remains an open question whether tradable permits are appropriate for use in transition and developing economies due to lack of institutions and expertise with market based policies. There are also many crucial design issues for the permit schemes as well as several competing instruments such as environmental taxes.

Those arguing in favor of market-based instruments emphasize that they are efficient instruments that relax the trade-off between economic growth and improved environmental quality, and that they can be achieved without specific knowledge of the technology or

\footnotetext{
- We are grateful to Åsa Löfgren, José Miguel Sánchez, Juan Pablo Montero, Enrique Calfucura, Gert Wagner, Paula Benavides and Felipe Zurita for helpful comments and to Marta Zamudio, Roberto Condori and Mabel Salazar for data on emissions and transactions.
} 
pollution-reduction costs of polluting sources. On the other hand, those opposed to the use of tradable permits programs in developing countries emphasize the lack of transparency and monitoring possibilities, the inadequate legal systems, and foremost the difficulties involved in creating a functioning market observed in less developed countries. [See Bell and Rusell (2002) and Bell (2004)]. However pervasive constraints would affect the performance of any instrument including both economic policies and command and command and control policies [Ellerman (2002)], although the implementation of more sophisticated policy instruments, as tradable emission permits, might require the decision maker to implement some particular institutional changes. For that reason, some market advocates argue that emissions taxes would be more appropriate, since they imply a change to an effective economic incentive system and raise revenue for environmental projects and programs. [See Eskeland et al. (1992), Krupnick (1997), Blackman and Harrington (2000)]. Finally, advocates of trading approaches argue that as countries develop and as economies and political systems become more willing to impose real environmental requirements, trading programs will become more adequate. Then, the important point is to start developing the institutions to build over the coming years now [See Krueger (2003)].

Many donors and advisors have promoted the use of market-based instrument as the key to more effective environmental protection in the developing world. [See O'Connor (1998)]. However, there has been rather limited experimentation with tradable permits in less developed countries, although efforts have been made in some transitional countries like Poland, Kazakhstan, the Czech Republic and the Slovak Republic to implement emission trading programs during the 1990s [See Zylicz (1995), Farrow (1999), Hauff and Missfeldt (2000) and Bell (2004)] and the academic and governmental interest in implementing emissions trading in China [See Ellerman (2002)]. In all these cases the main concern have been related to the transition from pre-existing environmental regulations to tradable emissions permits and the monitoring and enforcement capabilities that would be required in order to ensure compliance.

Santiago was one of the first cities outside OECD to implement a tradable permit program. The program launched in 1997 to control emissions coming from stationary sources of pollution has been characterized by a combination of failures affecting the attractiveness of trading: - over allocation of permits, high transaction costs, lack of clear penalties to 
sources in violation and several regulatory changes affecting the tenure over emission permits and hampering trade. The total amount of emission permits initially granted to incumbent sources has been decreased twice; the rate of offsetting has been raised twice while the program's rules have lead many sources to lose their emission permits because trade is only allowed within a specified period of time and banking permits is not possible. How has the emissions market reacted to these new regulations and conditions? Currently 46.3 percent of the initial mass of permits became void and 38 percent of this voided mass has been lost because incumbent sources did not trade before the legal deadline.

Why did sources not trade before the legal deadline? In this paper we analyze the design and implementation issues limiting the development of the tradable permit market in Santiago, as well as the challenges and advantages of applying tradable permits in less developed countries.

Previous studies evaluating the performance of the Santiago's trading program were done at early stages of its implementation. Montero et al. (2002) found that the grandfathering used to allocate emissions initially created economic incentives for incumbent sources to more readily declare their historic emissions in order to claim permits. O'Ryan et al. (2002) examined the impact of the introduction of natural gas in the applicability of the tradable permit program, concluding that this fuel increased the range of emissions potentially abated at a lower cost and reduced the efficiency gains from using a market based instrument. Finally, Palacios and Chavez (2005) evaluated the performance of the program in terms of enforcement, concluding that the aggregate level of over-compliance coexists with frequent violations of regulations by some of the sources. This paper goes more deeply into these issues using an updated database in order to analyze whether the program has improved through time and how it has reacted to regulatory adjustments and market shocks. The paper is organized as follows. The next section reviews the main lessons from the international experience with tradable permit programs. The third section describes the tradable permit program applied in Santiago. Then, the design and implementation issues limiting the development of the market are analyzed. The last section reviews the lessons that can be learnt from Santiago' experience and concludes. 


\section{THE USE OF TRADABLE PERMIT PROGRAMS IN DEVELOPED COUNTRIES}

Although the efficiency properties of tradable permit programs were discussed by some economists in the early 1970s [Dales, 1968; Montgomery, 1972], it was not until the early 80 s they started to be promoted in academia. The rise of interest occurred at the same time as many of the basic environmental laws were being written in the U.S. They were used to provide greater flexibility to firms charged with controlling air pollutant emissions (EPA's Emission Trading Programs), to phase out leaded gasoline and ozone-depleting chlorofluorocarbons (CFC) from the market and to reduce sulphur dioxides $\left(\mathrm{SO}_{2}\right)$ and nitrogen oxides (NOx) in the Los Angeles basin (RECLAIM). There was a gradual learning process concerning design issues that led up to the launching of the successful U.S. tradable permit program to control acid rain by cutting nationwide emissions of $\mathrm{SO}_{2}$.

Apart from the EU ETS program, the world's first large-scale $\mathrm{CO}_{2}$ emissions trading program, few applications of tradable permits existed previously in Europe, since taxes and other instruments have been used more frequently. The most important programs include the UK Emissions Trading Scheme (UK ETS), the Danish $\mathrm{CO}_{2}$ trading program, the Dutch offset programs and BP's internal experiment. On the other hand, very few applications have been implemented in transition or the developing countries. Chile and Singapore were pioneers in this matter while some pilot programs were introduced in Poland during the $1990 \mathrm{~s}^{1}$.

The experience with emissions trading over the past twenty-seven years offers some lessons concerning the use of tradable permits in controlling pollution [See Hahn and Hester (1989), Hahn (1989) Rico (1995), Stavins (1998), Schmalensee et al. (1998), Salomon (1999), Tietenberg (1999), Ellerman (2000), Stavins (2001), Boemare and Quirion (2002), Burtraw and Palmer (2003), Ellerman (2005), Victor and House (2006), Ellerman and Buchner (2007) and Convery and Redmont (2007)]. The first lesson concerns the functionality of emission trading as a regulatory instrument while the second lesson

\footnotetext{
${ }^{1}$ In 1991, the first pilot Project of emissions trading was carried out in Chorzow as an experiment following an agreement between the Minister of Environment and regional authorities. The project let several polluters in one of the most contaminated neighborhoods to jointly comply with individual emissions standards. Despite profound legal problems and a turbulent political environment against the policy, it led to a radical decrease of pollution and significant savings. (See Zylicz, 1995) There are also a large number of programs in various countries with tradable fishing quotas that have quite a few similarities with the programs we discuss here.
} 
concerns the features that make trading programs more efficient.

Regarding the first lesson, the overall experience with emissions trading is that it can work. To date, targeted emissions-reductions have been achieved and exceeded. Total abatement costs have been significantly less than what they would have been in the absence of trading and recent studies indicate that benefits exceed costs by a very significant margin [See Burtraw and Palmer (2003) and Chestnut et al. (2005)] while the trading volume has increased over time with a significant fraction of allowance transfers among economically unrelated parties.

As regards to the second lesson, there are several features that are important for emission trading to work. The most fundamental of these is that the rights to the environmental service or resource in question are allocated in a manner that creates some permanence and confidence. Additional features are realistic incentives to trade, spatial and temporal flexibility, the inclusion of the private sector fulfilling brokerage needs, monitoring and enforcement and the allocation of allowances. [See Appendix 1 for a comparison of selected features of emission trading programs implemented to date].

The right to trade must be clearly defined and not subject to case-by-case approval. Ellerman (2005) distinguishes between the incentives to trade provided by the three types of emissions trading: credit - based, allowance - based and averaging -based trading. In credit - based trading, credits can be created by reducing one source's emissions more than required by some pre-specified standard and transferring the credit to another source, which is thereby allowed to increase emissions above the standard. Although sources can propose trades, the final decision to create the credits and make the transfers rests with the regulator. On the other hand, in allowance- based trading rights to emit are created initially and distributed to sources, and there is no presumption that individual sources will limit emissions to the number of allowances they receive. They are free to trade allowances and the only requirement is that allowances equal emissions at the end of every compliance period. Averaging- based trading presumes a pre-specified standard of which emissions are traded, but subsequent trade between sources is not confined by regulatory approval. In practice, credit- based trading has not worked very well because of the high transaction costs associated with the creation and transfer of credits. The process of regulatory approval limited trading in the early EPA trading programs because of the uncertainty involved in 
getting individual trades. Quite the opposite, trading observed in allowance- based (RECLAIM and Acid Rain Program) and averaging- based programs (such as the Lead Phase-out) has been much greater.

If environmental damages do not depend on localization of emissions and monitoring costs are not disproportionate, trading program should include as many sources as possible. First, because the larger the number of participants, the larger the abatement cost differences among firms and the larger the benefits of trading. Second, because the risk of market power in the permit market is reduced. Flexibility allows for a broader set of compliance alternatives to be considered in terms of timing and spatial coverage. All of the US emissions trading programs, except RECLAIM, have included inter-temporal trading or "banking". Banking provides important flexibility for sources to undertake early reductions to accumulate allowances that can be used to ease compliance in the future, dampening the volatility of permit prices since it accommodates dynamic market changes and allow for shifts in industry structure with constant total emissions. According to Ellerman (2005) the Acid Rain program, the program with the greatest flexibility since it allows nationwide spatial trading and unlimited banking, has experienced price fluctuations of no more than 3:1 when measured as the ratio of the highest observed price to the lowest. In contrast, RECLAIM the most restricted program in the scope of spatial trading and that does not allow for banking, has experienced price fluctuations of 60:1.

It is clear that high transaction cost lower the effectiveness of tradable permits significantly. Transaction costs include the costs of finding an appropriate trading partner, establishing the terms of trade and completing the arrangements. The inclusion of the private sector fulfilling brokerage needs allows reducing these costs, increasing the economic incentives to trade. According to Tietenberg (1999), most observers of the early EPA emissions trading programs agree that fewer trades took place than necessary to achieve full costeffectiveness and that high transactions costs played a role in explaining this shortcoming. Anecdotal evidence can be found in the predominance of intra-firm (within firms) transactions over inter-firm (between firms) transactions. Further evidence is suggested by the role played by some states developing programs to assist firms in finding partners and minimizing administrative costs. [See Harrison (1999)]

Kerr et al. (1998) find evidence for the existence of transaction costs preventing trading in 
the lead phase out program because of under-developed brokerage and trading mechanisms. They estimate that the loss of cost effectiveness from these costs was around 10 to 20 percent and quite dependent on the characteristics of traders and the market, increasing when potential traders were small, unsophisticated and poorly integrated. Gangadharan (2000) also finds evidence for the existence of transaction costs during the initial years of the RECLAIM program. According to her, the absence of brokers increased the costs of finding a trading partner and the information costs of entering the market, reducing the probability of trading by about $32 \%$. The author also finds specific "learning by doing" effects in the permits market. The results suggest that increasing the number of times a facility enters the market reduces information costs until a certain point (15 trades) is reached. After that point, further increases in the number of trades seem to have no effect in reducing information costs further.

The Acid Rain program was consciously designed to minimize transaction costs. Rights were allocated according to principles that are quite transparent and remain constant for a long period. The auction market established as part of the sulfur allowance program reduced transaction costs by providing an easy means for buyers and sellers to transact, but also by providing systematic public information on prices that allowed private firms to provide a variety of trading services, like private brokerage, electronic bid/ask bulletin boards and permits price forecasts. The available data also allowed researchers to isolate the effects on transaction costs. Conrad et. al (1996) confirm that transaction costs have not significantly affected the trading and price of the $\mathrm{SO}_{2}$ program.

Monitoring and enforcement are important design issues to be considered. If not, trading programs do not provide enough incentives for a high degree of compliance. Compliance requires a matching of emissions and permits and for the technology to measure and to account allowances permanently. On the other hand, the enforcement of the programs depends not only on the technical ability to detect violations, but also on the legal ability to deal with them once detected setting effective sanctions.

Direct continuous monitoring of emissions has been an important factor in the success of the Acid Rain program. Rigorous checks and balances ensure compliance, system credibility, and integrity. Every allowance is assigned a serial number and EPA records transfers to make sure that a unit's emissions do not exceed the number of allowances it 
holds and makes this information available to the public.

Stranlund et al. (2002) analyze the compliance incentives faced by firms under the Acid Rain program and RECLAIM, stressing the importance of implementing fixed and automatic monetary penalties for emissions violations. While the $\mathrm{SO}_{2}$ apparently achieved a perfect compliance record, compliance rates in the RECLAIM program have ranged between 85 percent and 95 percent. Non compliance seems related to the uncertain value of monetary penalties, since under RECLAIM stated monetary penalties are maximum administrative penalties and actual sanctions are decided on a case-by-case basis.

A key issue in any tradable permit program is the initial allocation of permits. Despite a common preference for auctioned permits among economists, grandfathering to incumbent emitters has been applied in virtually all applications to date to gain political consensus for implementing the program. Only in the Acid Rain program, Singapore's CFC program and EU ETS program an auctioning scheme has been introduced. In the Acid Rain program a very small portion of the permits are auctioned out to make up for market imperfections and/or to accommodate newcomers to the market. Singapore's CFC auction of a half of the permits enables the government to appropriate a sizeable share of the scarcity rents, which is used to subsidize recycling services and the diffusion of information on alternative technologies. Finally, in the EU ETS program member states are allowed to auction up to 5 percent of their allowance in the first trading period and up to 10 percent in the second period but few countries make much use of this option.

But as it is shown by Sterner and Müller (2008), the incentives provided by free allocation schemes depend very much on the permit allocation rules and any rule where the firms can affect allocation (even indirectly in the future) will distort incentives and program efficiency. This was for example the case in the lead program where each refinery was allowed to average concentrations across the gallons it produced. Then, refineries and other agents gained more rights by selling more gasoline.

\section{SANTIAGO'S TRADABLE PERMIT PROGRAM}

In 1992, the Chilean environmental authority established a tradable permit program for total suspended particles (TSP) trying to control the adverse effects produced by the 
excessive level of this pollutant in Santiago. Due to their easy identification and their relative importance, the system focused on large boilers, which at the time accounted for more than 40 percent of total point sources emissions. Although the program became mandatory in 1994, it started in practice in 1997, giving the environmental authority two years to collect information on sources' emissions.

Environmental law regarding the tradable permit program rests mainly on two pieces of legislation: Supreme Decree 4 (promulgated in 1992) and Supreme Decree 16 (promulgated in 1998).

SD 4 established an individual cap for the emissions of industrial and residential boilers discharging emissions through a duct or stack at flow rates higher than $1000 \mathrm{~m}^{3} /$ hour (large boilers) and a tradable permit program that let this type of source exceed this cap through offsets from other large boilers. For that purpose, it distinguished between existing and new large boilers. Existing boilers are those installed or approved before 1992 that were endowed with emission permits called "initial daily emissions" (IDE). Each unit of IDE allows the holder to emit one kilogram of TSP daily. New large boilers are those installed or approved after that and were required to fully offset their emissions through abatement in existing large boilers. Emissions allowed to new large boilers are known as "daily permitted emissions" (DPE) and have the same characteristics as the IDE.

Since regulated sources were relatively small for the purpose of implementing sophisticated monitoring processes, the program was not designed on the basis of actual emissions but rather on a proxy variable equal to the maximum emissions that a source could emit in a given period of time. Thus, the daily cap on emissions of existing large boilers was calculated according to a formula that allowed them to emit a maximum given by the product of the maximum flow rate $\left(\mathrm{m}^{3} / \mathrm{hr}\right)$ of the gas exiting the stack times 24 hours of operation times a target on emissions concentration equal to $56^{*} 10^{-6}\left(\mathrm{~kg} / \mathrm{m}^{3}\right)$.

As the program progressed, PROCEFF came to realize that its initial allocation was too generous. SD 16 modified the quantity of allowed emissions to existing large boilers ${ }^{2}$. In

\footnotetext{
2 SD 16 also established a compensation program for industrial processes, intending to reduce particulate matter's and nitrogen oxide's emissions. The program would start the first of May, 2007. As large boilers, large processes were classified between existing and new ones In the case of particulate matter, existing processes would be granted emission permits equal to $50 \%$ of their actual emission in 1997 . In the case of nitrogen oxide, they would be granted $67 \%$ of their actual emissions in 1997 . New processes would offset $120 \%$ of their emissions of nitrogen oxide and $150 \%$ of their emissions of particulate matter.
} 
year 2000 the targeted emission concentration was decreased to $50 * 10^{-6}\left(\mathrm{~kg} / \mathrm{m}^{3}\right)$ and it was reduced again to $32 * 10^{-6}\left(\mathrm{~kg} / \mathrm{m}^{3}\right)$ in 2005 . The offsetting rate was also modified. Initially, it was set at $100 \%$, but in 1998 it was increased to $120 \%$ and in 2000 it was increased to $150 \%$.

Table 1 syntheses the main regulatory adjustments and program features.

Table 1: Outline of Santiago's Trading Program.

\begin{tabular}{|c|c|}
\hline Affected Sources & $\begin{array}{l}\text { Industrial and residential boilers discharging emissions through a duct or } \\
\text { stack at a flow rate higher than } 1000 \mathrm{~m}^{3} / \text { hour in Santiago. }\end{array}$ \\
\hline Covered Pollutants & Suspended particulates (kg/day) \\
\hline Permits Allocation & 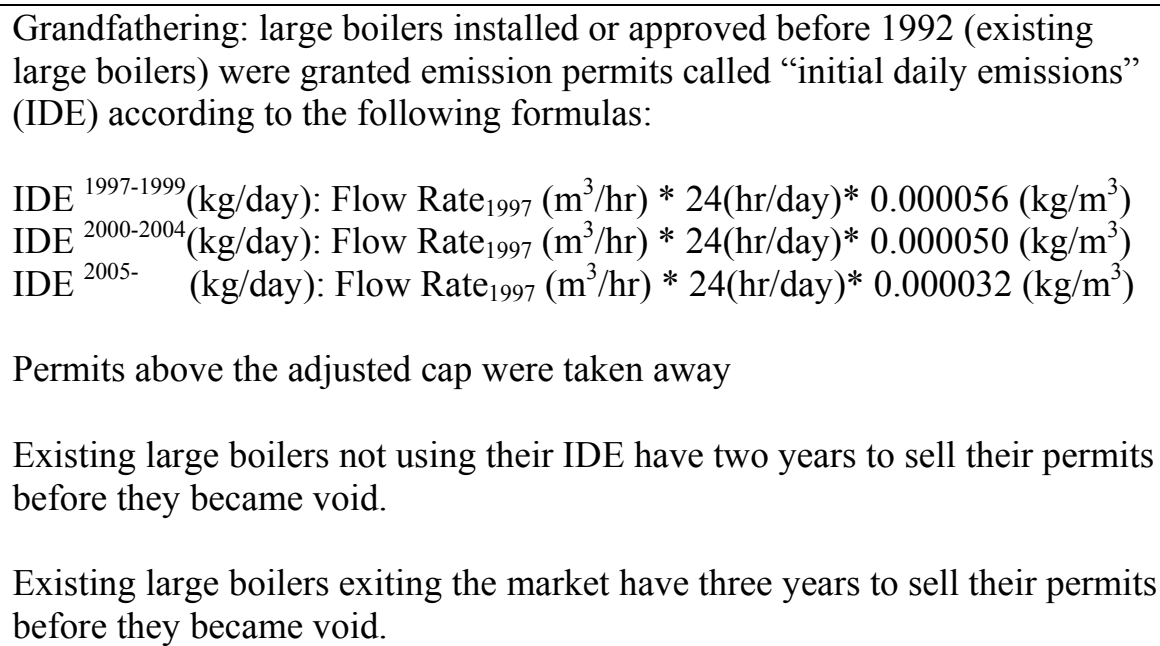 \\
\hline Offsetting rate & $\begin{array}{l}\text { 1997-1998: } 1.0 \\
\text { 1998-2000: } 1.2 \\
2000-\quad: 1.5\end{array}$ \\
\hline Emissions trading & $\begin{array}{l}\text { Credit - Based: all trades require approval by the regulatory agency, even } \\
\text { those trades among large boilers that share common ownership. }\end{array}$ \\
\hline Flexibility & $\begin{array}{l}\text { Banking : No } \\
\text { Borrowing: No }\end{array}$ \\
\hline $\begin{array}{l}\text { Administration of } \\
\text { emissions inventories } \\
\text { and permits accounts }\end{array}$ & $\begin{array}{l}\text { System maintained by regulatory agency. } \\
\text { Under-developed brokerage }\end{array}$ \\
\hline $\begin{array}{l}\text { Monitoring and } \\
\text { Reporting }\end{array}$ & $\begin{array}{l}\text { Annually } \\
\text { Self-reporting }\end{array}$ \\
\hline Penalties & Penalty fee ranging from US $\$ 4.50$ to US $\$ 90,000$ \\
\hline $\begin{array}{l}\text { Automatic monetary } \\
\text { penalties }\end{array}$ & $\begin{array}{l}\text { Monetary penalties are maximum administrative penalties and actual } \\
\text { sanctions are decided on a case-by-case basis }\end{array}$ \\
\hline
\end{tabular}


Santiago's tradable permit program is a credit based program. All trades require approval by the regulatory agency, even those trades among large boilers that share common ownership. Sources trying to offset their emissions must request the offset and find a partner, signing an offsetting agreement specifying the emissions to be compensated and the sources involved in the transaction (in the case of unrelated sources both steps must be legalized by a public notary) and finally, certifying the level of emissions of each source in the transaction through formal monitoring procedures. After all this paperwork, PROCEFF accepts or rejects the transaction or ask for additional information. If the transaction is accepted, a resolution grants the buyer a quantity of daily emission allowed.

Permits are given in perpetuity and large boilers are restricted to trade permits on a permanent basis. This feature of the program makes banking (and borrowing) of permits virtually impossible and it is an important restriction in the structure of the property rights that differentiates this scheme from the $\mathrm{SO}_{2}$ program in the US or the carbon rights in the European ETS, where permits are distributed on an annual basis and used to cover emissions in a particular year. As pointed out by Montero et al. (2002), a consequence of this feature of the program is to create an illiquid market where sources are uncertain about the availability of permits in the future and where buyers pay prices close to their chock prices even if in the aggregate there is an over supply of permits.

SD 16 established that those large existing boilers that were not using their IDE or those that wanted to exit the market had two and three years respectively to sell their permits before they became void. Therefore, IDEs have an expiration date and sources are not allowed to save credits for future use or sale for a long period.

Occasional brokers have provided information about trading partners and about the trading process. However, most sources have relied on the environmental authority to deliver such information, which is supposed to yearly provide an updated record of the IDEs and DPEs in force.

The program relies on self-reporting by regulated sources. The existing and new large boilers report emissions once a year to the program authorities. To comply with reporting requirements, sources must contact an independent and certified laboratory to conduct monitoring of the flow and the concentration of emissions discharged trough the stack. Dual sources, burning more than one fuel, are compelled to declare and offset their 
emissions as if they were using the dirtiest fuel. Thus there is no incentive for firms that use two fuels to use as much as possible of the cleaner fuel which is an unfortunate design detail.

Sources that do not comply with the reporting requirement face sanctions that can be imposed through an administrative procedure. Palacios and Chavez (2005) highlight two important features of the sanctions in Santiago's program. First, sanctions are not clearly specified. Secondly, they are not automatically imposed. In fact, according to them, sanctions might include a note of violation as well as a wide range of lump sum monetary sanctions, which range from US\$4.50 to US\$90,000. The level of the sanction actually imposed depends on an unclear way on each particular case, considering the extent of the emissions capacity permits violation and backsliding of the source, among other things. In addition, a prohibition on a source's operation is also possible, although quite infrequent.

The comparison between the features of the relatively successful $\mathrm{SO}_{2}$ programs and Santiago's program suggests two outcomes. First, transaction costs are expected to be significant because of the requirement for regulatory approval and the under-developed brokerage. Second, a significant rate of non compliance should be expected since monetary penalties are not clearly defined and actual sanctions are decided on a case-by-case basis.

\subsection{PERFORMANCE OF THE SANTIAGO'S TRADABLE PERMIT PROGRAM}

Table 2 summarizes some statistics about affected sources and shows the evolution of the stock of aggregate emission permits from 1997 to 2007. The summary was prepared using PROCEFF $^{3}$ databases and contains information about the number of sources in the program, the initial allocation of permits, the aggregate emissions, the offsetting of permits, the sources' flow rate, the emissions concentrations and the number of firms using cleaner fuels.

At the beginning of 1997, 4045.40 kilograms $^{4}$ of particulate matter emissions were allocated among 430 existing sources. Currently, only 53.7 percent of the initial mass of

\footnotetext{
${ }^{3}$ PROCEFF is the government office responsible for implementing and enforcing the environmental regulations intended to control fixed sources emissions.

${ }^{4}$ According to Montero et. al. (2002), this amount was estimated to be $64 \%$ of the aggregate emissions prior to the program.
} 
permits remains in force and $60 \%$ are in hands of new large boilers.

Notice that although the aggregate cap on emissions has been respected from the beginning, new sources did not offset their emissions during the first years of the program. Montero et. al. (2002) argues that one of the reasons behind this outcome was the lack of institutional capability to regulate stationary sources. Before permits could be allocated, it was necessary to develop a comprehensive inventory of sources and their historical emissions. Because of limited resources, the regulator concentrated all its regulatory activity on the completion of the inventory and the allocation of permits. The process lasted five years, and during that period, the regulator did not track trading activity, so there was no reconciliation of permits and emissions until the market began to take off at the end of 1998.

Table $\mathrm{N}^{\circ} 2$ also shows that permits in force have exceeded actual emissions from the beginning of the program. Two reasons explain this outcome. First, since the environmental authority had a poor historic record of sources' emissions at the time of implementation of the program, they overestimated the maximum amount of emissions that sources could potentially emit. Second, the fuel switching process made compliance more feasible.

About the first point, the environmental authority granted emission permits assuming a 24 hours level of activity. However, large boilers work on average 18 hours per day. Additionally, 128 sources that did not exist in 1997 received emission permits because they were operating at the time SD 4 was promulgated. These factors produced an immediate excess of permits in the hands of the initial holders.

The difference between permits in force and aggregate emissions has remained through time because the switching to cleaner fuels has led to a decrease in the aggregate emissions. Regarding this process, sources started to switch to cleaner fuels ${ }^{5}$ from 1995 onwards, in response to several environmental regulations. The most popular cleaner fuel was natural gas, which started to be imported from Argentina in 1997. After its arrival, it became the cheapest and cleanest fuel readily available. Thereby, a quick switching process started and currently about 50 percent of large boilers declare to use natural gas, although many of

\footnotetext{
${ }^{5}$ Sources started to switch to light oil, liquidified gas, kerosene and natural gas. All of them produce a lower emission concentration that the most demanding threshold imposed by the tradable permit program, which is $32 * 10^{-6}\left(\mathrm{~kg} / \mathrm{m}^{3}\right)$. For example, light oil and kerosene have an emission concentration equal to $30^{*} 10^{-6}\left(\mathrm{~kg} / \mathrm{m}^{3}\right)$ while this value decreases to $15^{*} 10^{-6}\left(\mathrm{~kg} / \mathrm{m}^{3}\right)$ in the case of liquefied and natural gas. Thereby, the switching allowed sources to over comply with the emissions' cap.
} 
them correspond to dual sources, burning also light oil.

Unfortunately, from 2004 onwards, Chile has faced severe restrictions over the amount of natural gas that can be imported, giving rise to the so called "natural gas crisis". Since then, large boilers have faced more and more severe restrictions over the quantity of natural gas available and they have again started to burn light oil, which has led to an increase in the aggregate emissions. In fact, aggregate emissions in 2007 were almost 27 percent larger than aggregate emissions in 2004. 
Table $N^{\circ} 2$ : Summary Statistics for Affected Sources

\begin{tabular}{|c|c|c|c|c|c|c|c|c|c|c|c|}
\hline Variable & 1997 & 1998 & 1999 & 2000 & 2001 & 2002 & 2003 & 2004 & 2005 & 2006 & 2007 \\
\hline Number of sources & 593 & 583 & 516 & 534 & 495 & 513 & 521 & 526 & 519 & 526 & 511 \\
\hline Existing sources & 430 & 402 & 332 & 324 & 286 & 277 & 273 & 264 & 251 & 235 & 217 \\
\hline New sources & 163 & 181 & 184 & 210 & 209 & 236 & 248 & 262 & 268 & 291 & 294 \\
\hline Permits in force (kg/day) & 4045.40 & 4044.40 & 4054.56 & 3710.37 & 3680.43 & 3087.34 & 2944.86 & 2856.05 & 2315.87 & 2204.17 & 2171.70 \\
\hline Initial daily emissions (IDE) & 4045.40 & 3963.36 & 3672.76 & 3195.08 & 2981.53 & 2162.52 & 1897.75 & 1746.98 & 1123.49 & 929.75 & 851.59 \\
\hline Daily permitted emissions (DPE) & 0 & 81.04 & 381.80 & 515.29 & 698.90 & 924.82 & 1047.11 & 1109.07 & 1192.38 & 1274.42 & 1320.11 \\
\hline Aggregate emissions (kg/day) & 2544.79 & 1804.60 & 865.75 & 824.55 & 650.21 & 603.59 & 649.76 & 624.33 & 688.51 & 848.59 & 791.73 \\
\hline Existing sources & 1684.27 & 1214.04 & 622.29 & 599.92 & 465.75 & 439.43 & 404.40 & 445.87 & 498.61 & 422.17 & 467.87 \\
\hline New sources & 860.52 & 590.56 & 243.46 & 224.63 & 184.46 & 164.16 & 245.37 & 178.46 & 189.91 & 426.42 & 323.86 \\
\hline Excess of Permits ${ }^{\text {(a) }}$ & 1500.60 & 2239.80 & 3188.80 & 2885.81 & 3030.22 & 2483.75 & 2295.10 & 2231.72 & 1627.35 & 1355.59 & 1379.97 \\
\hline Existing sources & 2361.13 & 2749.32 & 3050.47 & 2595.15 & 2515.78 & 1723.08 & 1493.36 & 1301.11 & 624.88 & 507.59 & 383.72 \\
\hline New sources & -860.52 & -509.52 & 138.34 & 290.66 & 514.44 & 760.66 & 801.74 & 930.61 & 1002.47 & 848.00 & 996.25 \\
\hline \multicolumn{12}{|l|}{ Flow rate $\left(\mathrm{m}^{3} /\right.$ hour$)$} \\
\hline Average & 4642.66 & 5131.59 & 4444.37 & 4444.98 & 5525.67 & 5415.96 & 5427.57 & 5349.46 & 5437.55 & 5947.64 & 6542.28 \\
\hline Standard deviation & 3892.18 & 4790.80 & 3733.36 & 3746.09 & 5799.30 & 5661.77 & 5595.13 & 5458.10 & 5583.59 & 5968.65 & 6843.83 \\
\hline Maximum & 182843.0 & 261304.7 & 182843.0 & 265122.3 & 610563.3 & 610563.3 & 610563.3 & 610563.3 & 610563.3 & 631607.2 & 773137.1 \\
\hline Minimum & 381.7 & 440.0 & 385.4 & 381.7 & 276.0 & 276.0 & 276.0 & 303.6 & 303.6 & 305.0 & 305.0 \\
\hline \multicolumn{12}{|l|}{ Concentration $\left(\mathrm{mg} / \mathrm{m}^{3}\right)$} \\
\hline Average & 87.58 & 83.62 & 49.72 & 35.81 & 21.17 & 16.53 & 13.36 & 11.57 & 10.63 & 10.30 & 11.32 \\
\hline Standard deviation & 47.46 & 49.98 & 23.84 & 21.61 & 12.79 & 9.57 & 7.48 & 6.98 & 6.38 & 6.65 & 8.30 \\
\hline Maximum & 629.50 & 915.00 & 111.20 & 110.70 & 110.10 & 97.80 & 92.50 & 91.80 & 94.60 & 98.40 & 352.40 \\
\hline Minimum & 8.80 & 8.80 & 2.60 & 2.70 & 2.70 & 1.30 & 1.50 & 0.50 & 0.90 & 0.10 & 0.30 \\
\hline \multicolumn{12}{|l|}{ Hours of operation } \\
\hline Average & 16.5 & 16.9 & 18.4 & 17.8 & 18.5 & 17.8 & 18.1 & 17.9 & 17.8 & 19.4 & 19.2 \\
\hline Standard deviation & 6.99 & 6.92 & 6.34 & 6.74 & 6.46 & 6.63 & 6.65 & 6.71 & 6.86 & 5.93 & 6.04 \\
\hline Maximum & 24 & 24 & 24 & 24 & 24 & 24 & 24 & 24 & 24 & 24 & 24 \\
\hline Minimum & 1 & 1 & 1.5 & 1.5 & 2 & 1 & 1.5 & 1.5 & 1 & 1 & 1 \\
\hline \multicolumn{12}{|l|}{ Number of sources using cleaner fuels } \\
\hline Using cleaner- non natural gas fuels & 214 & 265 & 246 & 239 & 210 & 186 & 189 & 171 & 160 & 176 & 215 \\
\hline Existing sources & 108 & 138 & 137 & 123 & 103 & 85 & 82 & 72 & 66 & 69 & 73 \\
\hline New sources & 106 & 127 & 109 & 116 & 107 & 101 & 107 & 99 & 94 & 107 & 142 \\
\hline Using natural gas & 0 & 54 & 131 & 162 & 204 & 231 & 228 & 234 & 222 & 277 & 221 \\
\hline Existing sources & 0 & 36 & 77 & 90 & 110 & 120 & 116 & 119 & 105 & 105 & 83 \\
\hline New sources & 0 & 18 & 54 & 72 & 94 & 111 & 112 & 115 & 117 & 172 & 138 \\
\hline
\end{tabular}

(a) Excess of permits corresponds to the difference between the permits in force and the aggregate emissions 
To better understand the impact that the lack of reliable data about sources' activity and the switching fuel process have had over the excess of permits, we can divide the excess into these two components. Thus, we calculate the excess of permits in force that would have been produced if the environmental authority would have allocated the initial cap based on the actual level of activity of existing sources. This excess corresponds then to the difference between the aggregate permits granted that would have been granted based on actual activity less the actual aggregate emissions.

Second, we calculate the excess of permits in force that would have been produced if existing sources would have accomplished the legal emissions' concentration target ${ }^{6}$ tightly and without over-compliance. Thus, this excess corresponds to the difference between the actual aggregate amount of permits granted and the aggregate emissions that would have been produced if existing sources would precisely accomplished the legal emissions' concentration target

The first counterfactual allows us to identify the effect of the overestimation of the maximum amount of emissions that sources emitted, while the second counterfactual allows identifying the effect of the switching process over the emissions' cap overcompliance.

Figure $\mathrm{N}^{\circ} 1$ shows the actual excess of permits beside both counterfactuals. Although the overestimation of the maximum amount of emissions emitted has some role explaining the excess of permits in force, the switching process seems to explain most of the excess throughout time. In fact, if affected sources would not have switched to cleaner fuels, aggregate emissions would have exceeded the aggregate permits for most of the period.

Notice that the initial overestimation of the required permits allowed accommodating the aggregate level of non compliance from new large boilers. If permits would not have granted in excess, the lack of offsetting would not have allowed accomplishing the cap on emissions.

\footnotetext{
${ }^{6}$ Where the legal emissions' concentration target is $0.000056\left(\mathrm{~kg} / \mathrm{m}^{3}\right)$ from 1997 to $1999,0.000050\left(\mathrm{~kg} / \mathrm{m}^{3}\right)$ from 2000 to 2004 and $0.000032\left(\mathrm{~kg} / \mathrm{m}^{3}\right)$ from 2005 onwards
} 
Figure $\mathrm{N}^{\circ} 1$ : Excess of Permits

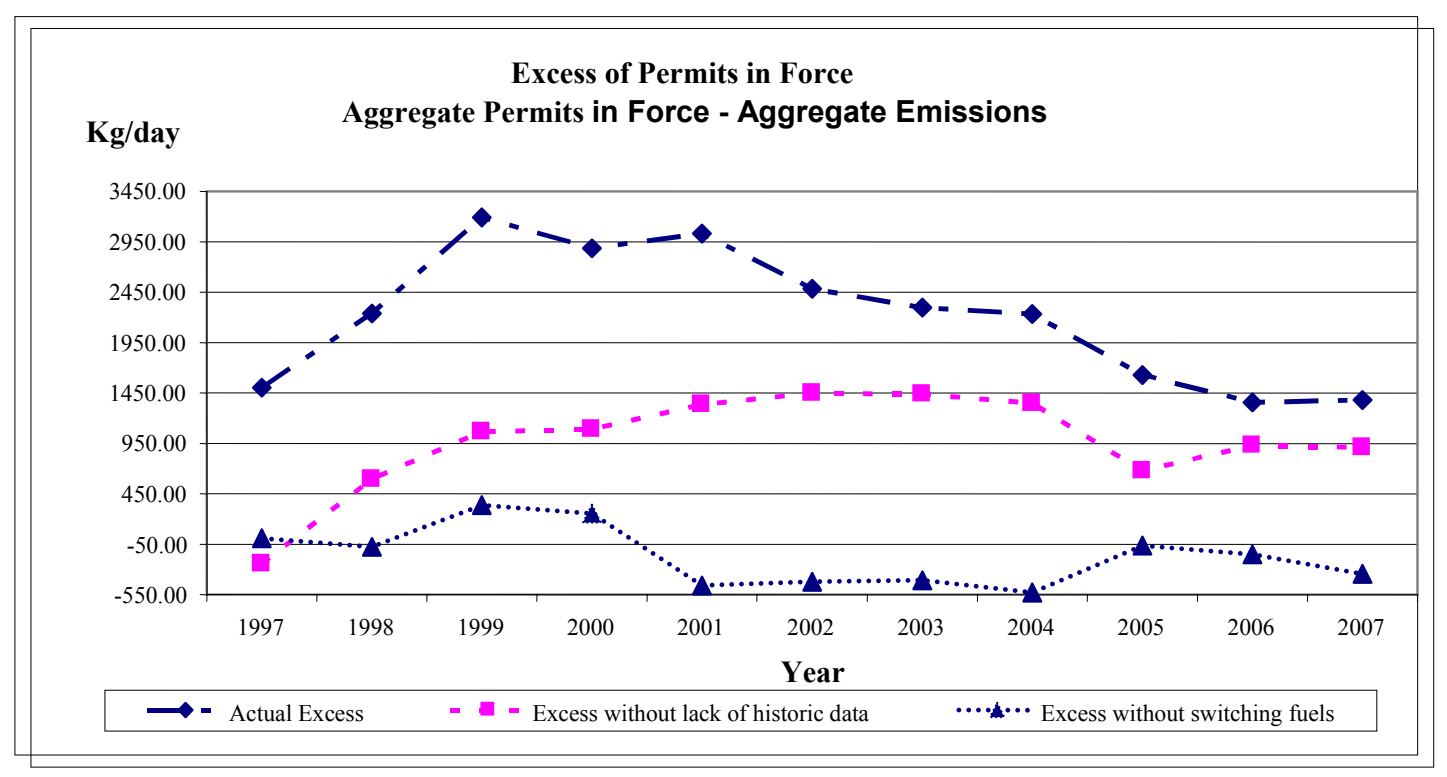

Source: Elaborated from data provided by PROCEFF

But as suggested by Palacios and Chavez (2005), aggregate over-compliance has coexisted with usual violations by some of the sources. Table $\mathrm{N}^{\circ} 3$ summarizes information about the incidence of individual violations of the emissions cap from 1997 to 2007 . Two types of violations are considered. Those produced when existing sources exceed the assigned IDE plus any net transfer and those produced when new sources do not cover their daily emissions with permits.

As expected, the enforcement design used in Santiago has not induced a high level of compliance, particularly in the case of new sources. On average, almost 30 percent of large boilers has not met their obligations with regards to the cap on emissions at some point in the sample, with almost 80 percent of these sources being new sources. The incidence of violations in both number and magnitude has decreased trough time, although the natural gas crisis broke this trend slightly. Since 2005 onwards the number of non complying existing sources has increased as well as the added violation increased. Before the switching they were burning dirtier fuels like coal, firewood and heavy oil. Their optimal response to the lack of natural gas has been starting to burn dirty fuels again, exceeding their emissions' cap and increasing the added violation.

Tradable permits are believed to promote "dynamic efficiency" because firms can expect to keep some or all of the gains from innovation trough reduced abatement costs plus reduced 
payments for permits. Considering that the switch to natural gas was quite important for compliance with the emissions cap, it is worth asking whether or not the tradable program had some role in encouraging sources to switch to cleaner fuels. ${ }^{7}$ Empirical evidence does not support such a hypothesis. According to Coria (2006), the lower price of natural gas seems to have been the main driver behind the switch while the tradable permit program had little or no effect. This result seems quite related to the features of the program. In fact, the aggregate excess of supply must have produced a very low permit price, making the benefits from saved emission permits irrelevant. Secondly, since dual sources were compelled to declare and offset their emissions as if they were using the dirtiest fuel, they had no expected gains from reduced payments for permits. Finally, the expected gains from reduced payments could have been also irrelevant since the lack of clearly defined monetary penalties and sanctions did not provide enough incentives for firms to take a high degree of compliance nor to invest in technologies to reduce emissions.

\footnotetext{
${ }^{7}$ Burtraw (2000) analyzes the innovation incentives under the Acid Rain program. He finds that innovation accounts for a large portion of the fall of the compliance costs over the last decade. However, innovation was already in the works prior to and independently of the program. Nonetheless, the allowance trading program deserves significant credit for providing the incentives and flexibility to accelerate and fully realize these exogenous changes that were occurring in the industry.
} 
Table 3: Compliance in the Santiago's Tradable Permit Program

\begin{tabular}{|c|c|c|c|c|c|c|c|c|c|c|c|}
\hline Variable & 1997 & 1998 & 1999 & 2000 & 2001 & 2002 & 2003 & 2004 & 2005 & 2006 & 2007 \\
\hline AccumulatedViolation (Kg/day) & 1255.19 & 811.03 & 289.11 & 246.55 & 156.07 & 112.32 & 198.18 & 153.84 & 175.05 & 197.93 & 221.26 \\
\hline Existing sources & 505.88 & 255.58 & 88.80 & 48.29 & 12.49 & 6.86 & 15.16 & 58.82 & 92.55 & 114.78 & 124.89 \\
\hline New sources & 749.31 & 555.45 & 200.31 & 198.26 & 143.57 & 105.47 & 183.02 & 95.01 & 82.50 & 83.15 & 96.37 \\
\hline Average Violation (Kg/day) & 4.61 & 3.41 & 1.50 & 1.27 & 1.11 & 0.90 & 1.62 & 1.27 & 1.58 & 1.66 & 1.80 \\
\hline Existing sources & 3.28 & 1.59 & 0.59 & 0.32 & 0.10 & 0.06 & 0.14 & 0.56 & 0.94 & 1.20 & 1.30 \\
\hline New sources & 4.87 & 3.45 & 1.34 & 1.30 & 1.21 & 0.94 & 1.71 & 0.90 & 0.84 & 0.87 & 1.00 \\
\hline Maximum Violation (Kg/day) & 89.19 & 89.19 & 28.3 & 25.63 & 21.60 & 9.12 & 92.8 & 40.74 & 45.09 & 56.96 & 45.09 \\
\hline Existing sources & 89.19 & 89.19 & 28.3 & 25.63 & 2.78 & 3.14 & 9.16 & 40.74 & 45.09 & 56.96 & 45.09 \\
\hline New sources & 65.60 & 45.14 & 18.48 & 21.60 & 21.60 & 9.12 & 92.8 & 7.0 & 23.76 & 14.16 & 15.49 \\
\hline Minimum Violation (Kg/day) & 0.008 & 0.008 & 0.010 & 0.006 & 0.006 & 0.002 & 0.036 & 0.030 & 0.018 & 0.005 & 0.030 \\
\hline Existing sources & 0.08 & 0.012 & 0.248 & 0.58 & 0.42 & 0.19 & 0.19 & 0.16 & 0.06 & 0.03 & 0.06 \\
\hline New sources & 0.008 & 0.008 & 0.010 & 0.006 & 0.006 & 0.002 & 0.036 & 0.030 & 0.018 & 0.005 & 0.003 \\
\hline Number of non complying sources & 272 & 238 & 193 & 194 & 140 & 125 & 122 & 121 & 111 & 119 & 123 \\
\hline Existing sources & 118 & 77 & 43 & 41 & 21 & 13 & 15 & 16 & 13 & 23 & 27 \\
\hline New sources & 154 & 161 & 150 & 153 & 119 & 112 & 107 & 105 & 98 & 96 & 96 \\
\hline$\%$ of non complying sources & $46 \%$ & $41 \%$ & $37 \%$ & $36 \%$ & $28 \%$ & $24 \%$ & $23 \%$ & $23 \%$ & $21 \%$ & $23 \%$ & $24 \%$ \\
\hline Existing sources & $20 \%$ & $13 \%$ & $8 \%$ & $8 \%$ & $4 \%$ & $3 \%$ & $3 \%$ & $3 \%$ & $3 \%$ & $4 \%$ & $5 \%$ \\
\hline New sources & $26 \%$ & $28 \%$ & $29 \%$ & $29 \%$ & $24 \%$ & $22 \%$ & $21 \%$ & $20 \%$ & $19 \%$ & $18 \%$ & $19 \%$ \\
\hline
\end{tabular}

(a) Souces violate the program when their emissions exceed their permits. Added violation corresponds to the addition of sources's violation 


\subsection{TRADING ACTIVITY AND TRANSACTION COSTS}

Table 4 shows the trading activity to date. So far, 240 transactions have been approved, involving 445 sources and a $39 \%$ of the initial mass of emission permits ${ }^{8}$. As expected, evidence suggests the important role played by transaction costs in the pattern of transactions. Around $76 \%$ of the transactions correspond to intrafirm (within firms) while $24 \%$ correspond to interfirm trading (between firms) transactions. Further evidence is suggested by the larger amount of emissions traded in interfirm transactions and because about $25 \%$ of the sources offsetting emissions have traded more than once (learning effect) ${ }^{9}$.

Table 4: Trading Activity

\begin{tabular}{|c|c|c|c|c|}
\hline \multicolumn{5}{|c|}{ Total Trading Activity } \\
\hline & \# sources & \# of transactions & Total kg/day & Average kg/day ${ }^{(a)}$ \\
\hline Aproved transactions & 445 & 240 & 1579.02 & 6.58 \\
\hline Intrafirm & 313 & 182 & 996.37 & 5.47 \\
\hline Interfirm & 132 & 58 & 582.65 & 10.05 \\
\hline Sources trading more than once & 114 & & & \\
\hline$N^{\circ}$ of Sellers & 221 & & & \\
\hline Existing Sources & 204 & & & \\
\hline New Sources & 17 & & & \\
\hline$N^{\circ}$ of Buyers & 224 & & & \\
\hline Existing Sources & 13 & & & \\
\hline New Sources & 211 & & & \\
\hline Sources that lost emission permits & 153 & & 798.95 & \\
\hline
\end{tabular}

(a) It corresponds to the ratio between the total $\mathrm{Kg} /$ day traded and the number of transactions

Table 5 shows some statistics about the length of time required to complete the transaction process. The average period required for a transaction to be approved is about 20.5 months. However, since at the beginning of the program there has been quite significant improvement. In fact, those transactions requested before 1998 needed more than 39

\footnotetext{
${ }^{8}$ In 1997, 15.2 millions of allowances were traded in the Acid Rain Program, a program characterized by low transaction costs. This amount represents approximately $15 \%$ of the total mass of allowances that year.

${ }^{9}$ Unfortunately, price information is not easy to obtain since sources do not have to inform to the environmental authority the price agreed for their transactions and because intrafirm transactions do not have an explicit price. However information from occasional brokers suggests that prices have ranged from US\$10.741(kg/day) in November of 1997, to US\$ 5.555 (kg/day) in March of 1998 and from US\$ 3704 (kg/day) in October of 2000 to US\$ 2144 (kg/day) in 2005.
} 
months to be approved ${ }^{10}$. Fortunately, the number of months the transaction process last has been trending downwards over time.

Surprisingly, intrafirm transactions required a longer period to be approved, suggesting that regulatory efforts were focused on reconciliation of permits and emissions between firms.

Table $\mathrm{N}^{\circ}$ 5: Transaction Process Period

\begin{tabular}{ccc}
\hline & Trading Process Period & \\
\hline Aproved Transactions & \% of Total Aproved Transactions & Average Period (in months) \\
Intrafirm & $\mathbf{1 0 0 \%}$ & $\mathbf{2 0 . 4 9}$ \\
Interfirm & $76 \%$ & 22.38 \\
& $24 \%$ & 17.03 \\
Transactions Required Before 1998 & & $\mathbf{3 9 . 2 1}$ \\
Intrafirm & $\mathbf{1 4 \%}$ & 39.23 \\
Interfirm & $76 \%$ & 39.13 \\
& $24 \%$ & $\mathbf{2 0 . 3 8}$ \\
Transactions Required 1998-2003 & & 21.60 \\
Intrafirm & $\mathbf{6 4 \%}$ & 17.98 \\
Interfirm & $72 \%$ & $\mathbf{8 . 5 5}$ \\
& $28 \%$ & 9.27 \\
Transactions Required From $\mathbf{2 0 0 4}$ & & 7.80 \\
Intrafirm & $\mathbf{2 2 \%}$ & \\
Interfirm & $50 \%$ & $50 \%$ \\
\hline
\end{tabular}

Apart from the transaction costs and the uncertainty involved in the trading activity, the long period it takes to the environmental authority to reconcile permits and emissions is also related to the high level of non-compliance from new large boilers. In fact, as it is show in the Table, it took several months for new large boilers requesting offsets to legally comply with the regulation. Thereby, non compliance it is not just related to the lack of clear and automatic penalties, but also to institutional failures making the compliance process uncertain and troublesome.

Since many large boilers are dual sources (light oil and natural gas) compelled to offset their emissions according to the dirtiest fuel, there is no reason to expect a significant increase in the trading activity because of the lack of natural gas. However, it could be

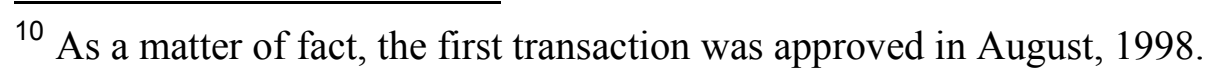


possible to expect an increase on the trading activity from single fuel large boilers. Therefore we have divided the sample period from 1998 to 2003 and from 2004 onwards. There is no evidence of an increase in the number of transactions approved from 2004. During the former period, the average number of transactions per year was equal to 26 . Since 2004, it was equal to 13 , although it has increased the rate of inter-firm transactions.

\subsection{POLICY ADJUSTMENTS}

Table 6 shows the effects of the policy adjustments described previously over the stock of emission permits. The increase in the rate of offsetting has reduced the total mass of permits by about $6.3 \%$. On the other hand, the decrease in the concentration target accounts for another $20.2 \%$ decrease on this mass. Finally, $17.3 \%$ of the mass has been lost because existing boilers did not trade or use their permits before the legal deadline.

Table 6: Decrease in the Emission Permits in Force

\begin{tabular}{lcc}
\hline \multicolumn{2}{c}{ Decrease In Emission Permits In Force } & \\
\hline & Total Kg per day & $\%$ \\
Total emissions allocated at 1997 & 4045,40 & $100,0 \%$ \\
Emissions reduced due to the increase in the rate of offsetting in $1998(1.2)$ & 126,92 & $3,1 \%$ \\
Emissions reduced due to the increase in the rate of offsetting in $2000(1.5)$ & 130,97 & $3,2 \%$ \\
Emissions reduced due to the decrease in concentration target in $2000\left(0.000050 \mathrm{Kg} / \mathrm{m}^{3}\right)$ & 331,10 & $8,2 \%$ \\
Emissions reduced due to the decrease in concentration target in $2005\left(0.000032 \mathrm{Kg} / \mathrm{m}^{3}\right)$ & 646,50 & $16,0 \%$ \\
Emissions lost due to non-trading & 638,20 & $17,3 \%$ \\
Total emission permits in force at 2007 & 2171,70 & $53,7 \%$ \\
\hline
\end{tabular}

Source: Elaborated from data provided by PROCEFF

Notice that the decrease in the amount of emission permits granted and the increase in the rate of offsetting have opposite effects on the attractiveness of trading. While the decrease in permits should have induced existing sources to trade before the decrease became binding, the increase in the rate of offsetting should have induced existing sources to retain permits if they were not sure of being able to buy permits back in the case they needed them. This second effect should increase over time since every time a new offsetting is produced, there is a net loss of permits in the market. 
Considering that $35 \%$ of the sources originally granted IDEs lost their emission permits, it is worth analyzing the reasons behind this outcome. Table 7 shows some statistics. More than 50 percent of the sources loosing permits are no longer operating, and 25 percent of them stopped operations before the implementation of the program in 1997. This evidence is consistent with the rent seeking behavior suggested by Montero et. al. (2002), who find that grandfathering the permits instead of auctioning off created economic incentives for incumbent sources (some of which were nonexistent at the time SD4 was promulgated) to more readily declare their emissions and claim the corresponding permits.

Did sources lose their permits because of transaction costs? If true, the incidence of smaller, older and poorly integrated sources loosing emission permits should be higher since the costs of engaging in the trading process are larger. Data supports this hypothesis. There are clear differences in the level of aggregate emissions, size (flow rate) and level of integration between sources that lost IDE and those that did not. In fact, the incidence of poorly integrated sources loosing emission permits is quite significant. Just $9.2 \%$ of these sources had related sources to trade. On the other side, $78.3 \%$ of those that did not lose permits have related partners. Thus, as expected, poorly integrated sources traded much less that integrated sources.

Table 7: Sources Granted with IDE

\begin{tabular}{|c|c|c|c|c|}
\hline \multicolumn{5}{|c|}{ Description of Sources Granted with IDE } \\
\hline \multirow[b]{2}{*}{ Number Sources } & \multicolumn{2}{|c|}{ Sources that lost IDE } & \multicolumn{2}{|c|}{ Sources that did not loose IDE } \\
\hline & 153 & $100.0 \%$ & 277 & $100.0 \%$ \\
\hline Not operating & 78 & $51.0 \%$ & 47 & $17.0 \%$ \\
\hline Not trading ever & 97 & $63.4 \%$ & 89 & $32.1 \%$ \\
\hline Had related sources in operation & 14 & $9.2 \%$ & 217 & $78.3 \%$ \\
\hline IDE (kg/day) & \multicolumn{2}{|c|}{7.31} & \multicolumn{2}{|r|}{10.26} \\
\hline Aggregate emissions in 1997 (kg/day) & \multicolumn{2}{|c|}{1.25} & \multicolumn{2}{|r|}{5.23} \\
\hline Flow rate in $1997\left(\mathrm{~m}^{3} /\right.$ hour $)$ & \multicolumn{2}{|c|}{3503.17} & \multicolumn{2}{|r|}{5516.16} \\
\hline
\end{tabular}

\section{WHAT CAN WE LEARN FROM SANTIAGO'S TRADABLE PERMIT PROGRAM?}

There is no doubt that despite of their theoretical advantages, tradable permit programs have been used far less frequently than command and control policies. Perhaps, one of the 
most significant barriers for this policy to be implemented is finding a political process that favors the introduction of market regulations in environmental management. This has been the case of Poland, where the main obstacle to the introduction of emissions trading during the 1990s was the low priority of the environmental issues combined with political controversies regarding the use of this market approach. But, according to Stavins (1998) the political process has gradually become more receptive to this policy instrument over the last decade. Currently, many donors and advisors are promoting the use of market-based instrument like tradable permit programs as the key to more effective environmental protection in economies in transition as well as in the developing countries. However, financial and institutional constraints have turned out to be main barriers, which may make the use of this environmental policy more problematic than in developed countries.

Before promoting the implementation of emission trading on economies in transition and in the developing world, we should review how developed countries have managed these issues to succeed. What have we learned about the requirements for tradable programs to work? Can less developed countries accomplish these requirements? In this paper, we study the performance of the tradable permit program implemented in Santiago, emphasizing the design and implementation issues that have limited the development of the emissions' market.

The review of successfully implemented trading program offers some lessons pointing out the importance of realistic incentives to trade, spatial and temporal flexibility, including privates fulfilling brokerage needs and monitoring and enforcement. Have these elements affected the performance of the Santiago's tradable program? They have. Requirements for prior regulatory approval and the under-developed brokerage have increased transaction costs while there is a significant rate of non compliance because monetary penalties are not clearly defined and actual sanctions are decided on a case-by-case basis. Additionally, the program is not temporally flexible. Permits must be traded on a permanent basis rather than annual basis, they have an expiration date and the banking option is not contemplated, so sources are not allowed to save credits for future use or sale for a long period.

Besides the long period of time required to complete the transaction, the incidence of a significant group of smaller, older and poorly integrated sources loosing emission permits because they did not trade before the legal deadline represents further evidence of the 
important role played by transaction costs preventing trading. On the other hand, the increase in the rate of non compliance as the optimal sources' response to the natural gas crisis reveals the important role played by the lack of enforcement.

But in spite of above described weaknesses, the aggregate cap on emissions have been met and the trading activity has increased trough time. However, is it likely that the high transaction costs has decreased trading, resulting that full cost-effectiveness has not been achieved.

A number of design modifications would have substantially improved the efficiency of the Santiago system:

- Better measurement of emissions at the time the program was implemented.

- More certain tenure over the permits

- Avoiding rules that hamper trade, as for instance, the offset rules that provide a bias against trade

- Banking should be allowed in some form.

Thus, Santiago's experience shows us that the challenges of designing successful environmental programs in less developed countries should not be underestimated. If the Chilean environmental authorities do not work out the current weaknesses in design, the success of the trading program will remain quite limited. Obvious additional recommendations to improve the performance of the market are looking for ways to reduce transaction costs and to improve monitoring and enforcement. Improving data system and public access to data can help with the first task. In fact, although the environmental authority is supposed to yearly provide an updated record of emission permits in force, information about actual emissions, violations and trading is not publicly available. Enhancing public access to this information can build credibility in the environmental program, allowing brokers to enter into the market to provide information about trading partners and about the trading process and finally, allowing society to exercise pressure over firms to improve their environmental performance.

But from the Chilean' experience we can also learn that are not clear reasons to believe that developing countries cannot benefit from the additional flexibility that tradable permits confer over more inflexible regulations. In fact, it took the USA some three or four decades of experimentation to learn how to design the institutions for a trading scheme. The Chilean 
scheme compares quite favorably with all the early US programs and to the European ETS scheme that in spite of being launched long after the Chilean scheme has roughly speaking the same number of flaws related to over allocation and lack of clear rules for penalties. Thus, one might thus say that this experience demonstrates that a middle-income country such as Chile is very capable of implementing this type of scheme even if much work remains before the design is really satisfactory.

\section{REFERENCES}

1) Bell, Ruth Greenspan and Russell, C. (2002): "Environmental Policy for Developing Countries", Issues in Science and Technology, Spring.

2) Blackman, A. and Harrington, W. (1999): "The Use of Economic Incentives in Developing Countries: Lessons from International Experience with Industrial Air Pollution", Discussion Paper 99-39, Resources for the Future.

3) Boemare, C. and Quirion, P. (2002): "Implementing greenhouse gas trading in Europe: lessons from economic literature and international experiences", Ecological Economics $43,213-230$.

4) Burtraw, D.;Krupnick, A.; Mansur, E,; Austin, D. and Farrell, D. (1997): "The Costs and Benefits of Reducing Acid Rain", Discussion Paper 97-31, Resources for the Future.

5) Burtraw, D. and Palmer, K. (2003): “The Paparazzi Take a Look at a Living Legend: The $\mathrm{SO}_{2}$ Cap-and-Trade Program for Power Plants in the United States", Discussion Paper 03-15, Resources For The Future.

6) Calfucura, E.; Coria, J and Sánchez, J.M. (2006):"Permisos Transables de Emisión en Chile: Lecciones, Desafíos y Oportunidades para Países en Desarrollo", Documento de Trabajo, Universidad Diego Portales.

7) Convery, Frank J. and Redmond, Luke (2007): "Market and Price Developments in the European Union Emissions Trading Scheme", "Review of Environmental Economics and Policy", volume 1, issue 1, pp 66-87.

8) Coria, J. (2006): "Environmental Policy, Fuel Prices and the Switching to Natural Gas in Santiago, Chile", unpublished document.

9) Chestnut, L. G. and Mills, D. M. (2005): “A fresh look at the benefits and costs of the 
US acid rain program”, Journal of Environmental Management 77, 252-266.

10) Dasgupta, S. and Laplante, B. (2001): "Pollution and Capital Markets in Developing Countries", Journal of Environmental Economics and Management 42, 310-335.

11) Dasgupta, S.; Hong, Jong Ho; Laplante, B. and Mamingi, N. (2006): "Disclosure of environmental violations and stock market in the Republic of Korea", Ecological Economics 58, 759-777.

12)Ellerman, A. Denny and Montero, Juan-Pablo (1998): "The Declining Trend in Sulfur Dioxide Emissions: Implications for Allowance Prices", Journal of Environmental Economics and Management, vol 36, 26-45.

13) Ellerman, A. Denny (2000): “Tradable permits for greenhouse gas emissions: a primer with particular reference to Europe", MIT Join Program Report No 69. http://web.mit.edu/globalchange/www/MITJPSPGC_Rpt69.pdf.

14)Ellerman, A. Denny (2002): "Designing a tradable permit system to control SO2 emissions in China: Principles and practice”. Energy Journal 23 (2): 1-26.

15) Ellerman, A. Denny (2005): "US experience with emissions trading: lessons for CO2 emissions trading", in: Emissions Trading for Climate Policy: US and European Perspectives, Cambridge University Press.

16) Ellerman, A. Denny and Buchner, Barbara K. (2007): "Review of Environmental Economics and Policy", volume 1, issue 1, pp 66-87.

17)Farrow, Scott (1999): "The duality of taxes and tradable permits: A survey with applications in Central and Eastern Europe", Environment and Development Economics 4, 519-535.

18) Gangadharan, Lata (2000): "Transaction Costs in Pollution Markets: An Empirical Study", Land Economics 76(4), November, pp 601-614

19) Garcia, J.; Sterner, T. and Afsah, S. (2007): "Public disclosure of industrial pollution: the PROPER approach for Indonesia?, Environment and Development Economics 12, 739-756.

20)Hahn, R. and Hester, G. (1989): "Marketable Permits: Lessons for Theory and Practice", Ecology Law Quarterly 16, 361-406.

21)Hahn, R. (1989): "Economics Prescriptions for Environmental Problems: How the Patient Followed the Doctor's Orders, The Journal of Economic Perspectives, Vol 3, 
No. 2, pp 95-114.

22) Harrison, David (1999): "Implementing Domestic Tradable Permits for Environmental Protection", OECD.

23) Hauff, J. and Missfeldt, Fanny (2000): "Should Poland Implement Domestic Emissions Trading?, Review of European Community \& International Law, Vol 9, issue 3, 252263.

24) Kerr, S. and Maré, D. (1998): "Transaction Costs and Tradable Permit Markets: The United States Lead Phasedown, New Zealand Department of Labour.

25) Konar, S and Cohen, M.A. (1997): "Information as regulation: the effect of community right to know laws on toxic emissions" Journal of Environmental Economics and Management 32, 109-124.

26) Krueger, J.; Grover, K. and Schreifels, J. (2003): "Building Institutions to Address Air Pollution in Developing Countries: The Cap and Trade Approach", OECD Global Forum On Sustainable Development: Emissions Trading, Concerted Action On Tradable Emissions Permits Country Forum.

27) O' Connor, D. (1998): “Applying Instruments in Developing Countries: From Theory to Implementation", Environmental and Development Economics, Vol. 4, pp 91-110.

28) O’Ryan, Raúl (1996): “Cost- Effective Policies to Improve Urban Air Quality in Santiago, Chile", Journal of Environmental Economics and Management 31, 302-313.

29) O’Ryan, Raúl (2002): “Emissions Trading in Santiago: Why Has It Not Worked, But Been Successful?", Unpublished document, Program for Environmental Economics and Management, Industrial Engineering Department, Universidad de Chile.

30) Montero, J.P.: "Optimal design of a phase-in emissions trading program", Journal of Public Economics 75, 273-291.

31) Montero, J.P.; Sanchez, J.M. and Katz, R. (2002):"A Market- Based Environmental Policy Experiment in Chile", Journal of Law and Economics, vol. XLV, April, pp 267287.

32) Palacios, M. and Chavez, C. (2005):"Determinants of compliance in the emissions compensation program in Santiago, Chile", Environment and Development Economics 10: $453--483$.

33) Rico, Renee (1995): “The U.S. Allowance Trading System for Sulfur Dioxide: An 
Update on Market Experience", Environmental and Resource Economics 5, 115-129.

34) Salomon, Barry D. (1999): "New Directions in emission trading: the potential contribution of new institutional economics", Ecological Economics 30, 371-387.

35) Schmalensee, R.; Joskow, P.; Ellerman, D. and Montero, J.P. (1998):"An Interim Evaluation of Sulfur Dioxide Emissions Trading", The Journal of Economics Perspectives, Vol. 13, $\mathrm{N}^{\circ}$ 3, pp 53-68.

36) Shabman, L., Stephenson, K. and Shobe, W. (2002): "Trading programs for environmental management: reflections on the air and water experiences", Environmental Practice 4: 153-162.

37) Stavins, Robert (1998): "What Can We Learn from the Grand Policy Experiment? Lessons from $\mathrm{SO}_{2}$ Allowance Trading. Journal of Economic Perspectives 12, no. 3, 69-88.

38) Stavins, Robert (2001): "Experience with Market-Based Environmental Policy Instruments", The Handbook of Environmental Economics, Edited by Karl-Göran Mäler and Jeffrey Vincent.

39) Sterner, T. and A. Müller (2008), 'Output and Abatement Effects of Allocation Readjustment in Permit Trade', Climatic Change (vol. 86 pp33-49)

40) Stranlund, J.K., Chavez, C.A., Field, B.C. (2002): "Enforcing emission trading programs: Theory, practice and performance", Policy Studies Journal, Vol 30, № 3, 343-361.

41) Tietenberg, Tom (1999): “Tradable Permits Approaches to Pollution Control: Faustian Bargain or Paradaise Regained? In: Kaplowitz, M.D. (Ed.), Property Rights, Economics, and the Environment. JAI Press, Stanford, CT.

42) Tietenberg, Tom (2002): "The Tradable Permits Approach to Protecting The Commons: What Have We Learned? Fondazione Eni Enrico Mattei, NOTA DI LAVORO 36.2002.

43) Toman, M.; Cofala, J. and Bates, R. (1994): “Alternative Standards and Instruments for Air Pollution Control in Poland", Environmental and Resource Economics 4, 401-417.

44) Victor, David G. and House, Joshua C. (2006): "BP's emissions trading system", Energy Policy 34, 2100-2112.

45)Zylicz, Tomas (1995): "Cost-Effectiveness of Air Pollution Abatement in Poland", Environmental and Resource Economics 5, 131-149. 


\section{Appendix 1: Comparison of Emission Trading Programs}

\begin{tabular}{|c|c|c|c|c|c|c|c|c|}
\hline $\begin{array}{l}\text { Program and } \\
\text { objective }\end{array}$ & $\begin{array}{l}\text { Affected } \\
\text { Sources }\end{array}$ & $\begin{array}{l}\text { Covered } \\
\text { Pollutants }\end{array}$ & $\begin{array}{l}\text { Permits } \\
\text { Allocation }\end{array}$ & $\begin{array}{l}\text { Emissions } \\
\text { trading }\end{array}$ & Flexibility & $\begin{array}{l}\text { Monitoring } \\
\text { and } \\
\text { Reporting }\end{array}$ & Penalties & $\begin{array}{l}\text { Automatic } \\
\text { monetary } \\
\text { penalties } \\
\end{array}$ \\
\hline $\begin{array}{l}\text { EPA Emission } \\
\text { Trading } \\
\text { Program } \\
\text { Cut nation-wide } \\
\text { emission of } \\
\text { several } \\
\text { pollutants }\end{array}$ & $\begin{array}{l}\text { Firms } \\
\text { emitting } \\
\text { controlled air } \\
\text { pollutants }\end{array}$ & $\begin{array}{l}\text { Volatile organic } \\
\text { compounds, } \\
\text { carbon monoxide, } \\
\text { sulfur dioxide, } \\
\text { particulates and } \\
\text { nitrogen oxides }\end{array}$ & Grandfathering & $\begin{array}{l}\text { Credit based, } \\
\text { netting is } \\
\text { subject to } \\
\text { approval at the } \\
\text { state level, } \\
\text { offsets and } \\
\text { bubbles are } \\
\text { subject to } \\
\text { approval at the } \\
\text { federal level }\end{array}$ & $\begin{array}{l}\text { Banking. } \\
\text { Netting only } \\
\text { allows intra } \\
\text { firm trading, } \\
\text { offsets and } \\
\text { bubbles } \\
\text { allow intra } \\
\text { and inter } \\
\text { firm trading, }\end{array}$ & $\begin{array}{l}\text { No } \\
\text { additional } \\
\text { monitoring } \\
\text { requirements } \\
\text { beyond } \\
\text { those } \\
\text { incorporated } \\
\text { into existing } \\
\text { air quality } \\
\text { regulations. } \\
\text { Enforcement } \\
\text { is implement } \\
\text { through } \\
\text { periodic } \\
\text { facility } \\
\text { inspections } \\
\text { to ensure } \\
\text { that } \\
\text { pollution } \\
\text { control } \\
\text { equipment is } \\
\text { installed, } \\
\text { operating } \\
\text { and meeting } \\
\text { the } \\
\text { regulatory } \\
\text { requirements }\end{array}$ & & \\
\hline
\end{tabular}




\begin{tabular}{|c|c|c|c|c|c|c|c|c|}
\hline $\begin{array}{l}\text { EU ETS } \\
\text { Cut emissions } \\
\text { of member } \\
\text { states during } \\
\text { the Kyoto } \\
\text { period }\end{array}$ & $\begin{array}{l}\text { Energy- } \\
\text { intensive } \\
\text { industries: } \\
\text { iron and } \\
\text { steel, certain } \\
\text { minerals } \\
\text { industries, } \\
\text { energy } \\
\text { production } \\
\text { and pulp and } \\
\text { paper. }\end{array}$ & Carbon dioxide & $\begin{array}{l}\text { Member states } \\
\text { freely allocate } \\
\mathrm{CO}_{2} \text { emissions } \\
\text { to incumbents } \\
\text { and new } \\
\text { entrants on the } \\
\text { basis of the } \\
\text { National } \\
\text { Allocation Plan. } \\
\text { Member states } \\
\text { are allowed to } \\
\text { auction up to } 5 \\
\text { percent of their } \\
\text { total allowance } \\
\text { allocation. }\end{array}$ & $\begin{array}{l}\text { Cap an trade } \\
\text { Overall cap on } \\
\text { total emissions } \\
\text { from all } 25 \\
\text { member } \\
\text { countries equal } \\
\text { to the EU } \\
\text { commitment } \\
\text { under the Kyoto } \\
\text { Protocol. } \\
\text { National cap } \\
\text { equal to national } \\
\text { allowances } \\
\text { under the Kyoto } \\
\text { Protocol. }\end{array}$ & $\begin{array}{l}\text { Banking and } \\
\text { borrowing } \\
\text { are allowed } \\
\text { within each } \\
\text { phase (2005- } \\
2007 ; 2008- \\
2012) \text {. }\end{array}$ & $\begin{array}{l}\text { Continuous } \\
\text { emissions } \\
\text { Monitoring } \\
\text { is optional. } \\
\text { Most } \\
\text { installations } \\
\text { are expected } \\
\text { to use } \\
\text { emission } \\
\text { factors } \\
\text { coupled with } \\
\text { fuel use or } \\
\text { production } \\
\text { data to } \\
\text { calculate } \\
\text { their } \\
\text { emissions. }\end{array}$ & $\begin{array}{l}€ 40 \text { per ton of } \\
\mathrm{CO}_{2} \text { in the first } \\
\text { phase. } \\
€ 100 \text { per ton of } \\
\mathrm{CO}_{2} \text { in the } \\
\text { second phase. } \\
\text { Additional } \\
\text { administrative } \\
\text { and criminal } \\
\text { penalties are left } \\
\text { to the members } \\
\text { states. }\end{array}$ & Yes \\
\hline $\begin{array}{l}\text { Lead Phase- } \\
\text { Out } \\
\text { Phase out } \\
\text { leaded gasoline } \\
\text { from 1979- } \\
1987\end{array}$ & $\begin{array}{l}\text { petroleum } \\
\text { refineries, } \\
\text { national } \\
\text { system }\end{array}$ & Leaded gasoline & $\begin{array}{l}\text { Permits } \\
\text { allocated } \\
\text { quarterly based } \\
\text { on leaded } \\
\text { gasoline } \\
\text { production in } \\
\text { that quarter. }\end{array}$ & $\begin{array}{l}\text { Averaging } \\
\text { Based }\end{array}$ & $\begin{array}{l}\text { Banking was } \\
\text { allowed for } \\
\text { the latter } \\
\text { portion of } \\
\text { the } \\
\text { programme. }\end{array}$ & $\begin{array}{l}\text { Self } \\
\text { monitoring, } \\
\text { each quarter } \\
\text { refineries } \\
\text { must submit } \\
\text { a report on } \\
\text { their } \\
\text { gasoline } \\
\text { usage and } \\
\text { lead usage }\end{array}$ & $\begin{array}{l}\text { Most disputes } \\
\text { administratively } \\
\text { settled, with few } \\
\text { court actions. }\end{array}$ & Yes \\
\hline $\begin{array}{l}\text { Phase-Out of } \\
\text { Ozone } \\
\text { Depleting } \\
\text { Substances } \\
\text { (ODS) } \\
\text { Phase out CFC } \\
\text { and halons } \\
\text { from 1989- } \\
1995\end{array}$ & $\begin{array}{l}28 \mathrm{CFC} \text { and } \\
\text { halons } \\
\text { producers } \\
\text { and } \\
\text { importers }\end{array}$ & $\begin{array}{l}\text { Five major } \\
\text { chlorofluorocarbo } \\
\text { ns } \\
\text { (CFC) and halons }\end{array}$ & Grandfathering & $\begin{array}{l}\text { Credit based, } \\
\text { trades require } \\
\text { approval by the } \\
\text { regulatory } \\
\text { agency }\end{array}$ & $\begin{array}{l}\text { Banking. } \\
\text { Intra-firm } \\
\text { inter-firm } \\
\text { inter- } \\
\text { pollutant } \\
\text { and between } \\
\text { nations that } \\
\text { signed the } \\
\text { Montreal } \\
\text { Protocol }\end{array}$ & $\begin{array}{l}\text { Self } \\
\text { reporting of } \\
\text { production } \\
\text { levels, } \\
\text { imports, } \\
\text { exports and } \\
\text { "recycled" } \\
\text { ODS }\end{array}$ & $\begin{array}{l}\text { U\$ } 25000 \text { per } \\
\text { kilogram. } \\
\text { Possible illegal } \\
\text { labeling of } \\
\text { imported and } \\
\text { exported ODS } \\
\text { as "recycled". }\end{array}$ & Yes \\
\hline
\end{tabular}




\begin{tabular}{|c|c|c|c|c|c|c|c|c|}
\hline $\begin{array}{l}\text { US Acid Rain } \\
\text { Program } \\
\text { Cut nation-wide } \\
\text { emission } 50 \% \\
\text { below } 1980 \\
\text { levels by } 2010 \text {. }\end{array}$ & $\begin{array}{l}\text { electricity } \\
\text { generating } \\
\text { units ( } 2000 \\
\text { U) } \\
\text { national } \\
\text { system }\end{array}$ & Sulfur dioxide & $\begin{array}{l}\text { Grandfathering } \\
\text { And auctions }\end{array}$ & $\begin{array}{l}\text { Allowance } \\
\text { based }\end{array}$ & unrestricted & $\begin{array}{l}\text { Continuous } \\
\text { emissions } \\
\text { monitoring } \\
\text { obligatory } \\
\text { for all } \\
\text { sources }\end{array}$ & U\$ 2000 per ton & Yes \\
\hline $\begin{array}{l}\text { RECLAIM } \\
\text { Cut local } \\
\text { emission } 80 \% \\
\text { below } 1990 \\
\text { levels by } 2003 \text {. }\end{array}$ & $\begin{array}{l}\text { point sources } \\
\text { emitting } \\
\text { more than } 4 \\
\text { ton/year } \\
\text { (electric } \\
\text { generating } \\
\text { units are } \\
\text { excluded of } \\
\text { the } \mathrm{SO}_{2} \\
\text { program) } \\
\text { local system, } \\
\text { South Coast } \\
\text { of California }\end{array}$ & $\begin{array}{l}\text { Sulfur dioxide } \\
\text { and nitrogen } \\
\text { oxide }\end{array}$ & Grandfathering & $\begin{array}{l}\text { Allowance } \\
\text { based }\end{array}$ & $\begin{array}{l}\text { No banking } \\
\text { no } \\
\text { borrowing }\end{array}$ & $\begin{array}{l}\text { Continuous } \\
\text { emissions } \\
\text { monitoring } \\
\text { obligatory } \\
2 / 3 \text { of } \\
\text { sources, } \\
\text { other less } \\
\text { strict } \\
\text { methods }\end{array}$ & $\begin{array}{l}\text { up to U\$500 per } \\
\text { violation }\end{array}$ & No \\
\hline $\begin{array}{l}\text { Denmark } \\
\mathrm{Cut}^{\mathrm{CO}_{2} \text { nation }} \\
\text { wide emissions } \\
70 \% \text { below } \\
1998 \text { levels by } \\
2003\end{array}$ & $\begin{array}{l}\text { Electricity } \\
\text { producers } \\
\text { and } \\
\text { associations } \\
\text { of electricity } \\
\text { producers } \\
\text { which } \mathrm{CO}_{2} \\
\text { emissions } \\
\text { above } \\
100.000 \text { tons } \\
\text { per year, } \\
\text { national } \\
\text { system }\end{array}$ & Carbon dioxide & $\begin{array}{l}\text { Grandfathering, } \\
\text { a portion of } \\
\text { quotas is } \\
\text { withhold by the } \\
\text { Minister for } \\
\text { Environment for } \\
\text { new entrants }\end{array}$ & & Banking & $\begin{array}{l}\text { Self } \\
\text { monitoring, } \\
\text { annually } \\
\text { reports }\end{array}$ & $\begin{array}{l}\text { U\$ } 6 \text { per ton of } \\
\mathrm{CO}_{2}\end{array}$ & \\
\hline $\begin{array}{l}\text { The } \\
\text { Netherlands } \\
\text { NOx emission }\end{array}$ & $\begin{array}{l}\text { stationary } \\
\text { sources } \\
\text { larger than }\end{array}$ & NOx & $\begin{array}{l}\text { Free yearly } \\
\text { allocation of } \\
\text { NOx emissions }\end{array}$ & $\begin{array}{l}\text { Averaging } \\
\text { based }\end{array}$ & $\begin{array}{l}\text { banking and } \\
\text { borrowing } \\
\text { is restricted }\end{array}$ & $\begin{array}{l}\text { Self } \\
\text { monitoring, } \\
\text { annually }\end{array}$ & $\begin{array}{l}\text { To be worked } \\
\text { out }\end{array}$ & \\
\hline
\end{tabular}




\begin{tabular}{|c|c|c|c|c|c|c|c|c|}
\hline $\begin{array}{l}\text { permits } \\
\text { Cut NOx nation } \\
\text { wide emissions } \\
50 \% \text { below } \\
1995 \text { levels by } \\
2010\end{array}$ & $\begin{array}{l}20 \mathrm{MW} ; \\
\text { about } 250 \\
\text { firms }\end{array}$ & & $\begin{array}{l}\text { on the basis of } \\
\text { performance } \\
\text { standards per } \\
\text { facility }\end{array}$ & & $\begin{array}{l}\text { to } 5 \% \text { of one } \\
\text { year's } \\
\text { allowances }\end{array}$ & reports & & \\
\hline 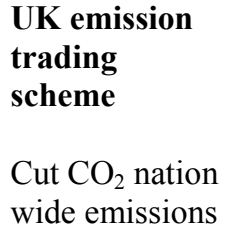 & $\begin{array}{l}\text { Voluntary } \\
\text { scheme } \\
\text { through } \\
\text { financial } \\
\text { incentives }\end{array}$ & $\mathrm{CO}_{2}$ & $\begin{array}{l}\text { Grandfathering } \\
\text { based on output. }\end{array}$ & & & & $\begin{array}{l}\text { Negotiated } \\
\text { agreement, } \\
\text { source loose } \\
80 \% \text { tax } \\
\text { reduction }\end{array}$ & \\
\hline $\begin{array}{l}\text { BP's emissions } \\
\text { trading } \\
\text { Cut BP's } \\
\text { emissions 10\% } \\
\text { below } 1990 \\
\text { levels }\end{array}$ & $\begin{array}{l}\text { BP's } \\
\text { business } \\
\text { units (BU) }\end{array}$ & $\mathrm{CO}_{2}$ & $\begin{array}{l}\text { Grandfathering } \\
\text { based on } \\
\text { emissions. } \\
\text { For new BU, } \\
\text { permits were } \\
\text { allocated based } \\
\text { on a forecast. }\end{array}$ & $\begin{array}{l}\text { Bilateral trades } \\
\text { trough a central } \\
\text { broker. }\end{array}$ & $\begin{array}{l}\text { BUs could } \\
\text { bank up to } \\
5 \% \text { of their } \\
\text { allocation } \\
\text { for future } \\
\text { use. }\end{array}$ & & $\begin{array}{l}\text { Emissions goals } \\
\text { were written } \\
\text { into the } \\
\text { performance } \\
\text { contracts of the } \\
\text { business unit } \\
\text { leaders. }\end{array}$ & No \\
\hline $\begin{array}{l}\text { Singapore } \\
\text { Phase out CFC } \\
\text { from } 1980\end{array}$ & $\begin{array}{l}\text { CFC } \\
\text { producers } \\
\text { and } \\
\text { importers }\end{array}$ & $\mathrm{CFC}$ & $\begin{array}{l}\text { Grandfathering } \\
\text { and auctions, } \\
\text { quarterly } \\
\text { allocation of } \\
\text { quotas }\end{array}$ & & $\begin{array}{l}\text { no banking } \\
\text { no bilateral } \\
\text { trading }\end{array}$ & & & \\
\hline
\end{tabular}

Source: Based on Hahn and Hester (1989), Hahn (1989) Rico (1995), Stavins (1998), Schmalensee et al. (1998), Salomon (1999), Harrison (1999), Tietenberg (1999), Ellerman (2000), Stavins (2001), Boemare and Quirion (2002), Ellerman (2005), David and House(2006) and Ellerman and Buchner (2007). 